
\title{
大阪市における市民に好まれる風景構造に関する研究
}

\section{A Study on the Favored Scenery Structure of Citizen in Osaka City}

\author{
王 莣* 下村 泰彦* 加我 宏之* 増田 昇* \\ Rui WANG Yasuhiko SHIMOMURA Hiroyuki KAGA Noboru MASUDA
}

\begin{abstract}
This study was carried out to seek the favored scenery structure of the city dwellers in Osaka City by analyzing the relationship between the scenery and the landform or the land use. As a result, the following becomes clear. First, even if the city accumulation is remarkable in downtown of Osaka, the space composed of natural elements such as the woods, the row, the surface of the water and so on is important. Second, in the commercial area which spreads to the west side on the Uemachi plateau, the city basis facilities such as the avenue which produces rich scenery are important. Moreover, the trenches or the rivers which leave the personality of Water City Osaka are important. Third, in the residential area which spreads to the southern part and the eastern part on the Uemachi plateau, the neighborhood green of human scale and the living scenery from the old days are attractive. Fourth, the characteristic of the Uemachi plateau and the characteristic of the history are lost. Fifth, in the industrial area which spreads to the estuary part and on the sea, the new viewpoint places such as the tall building and the ship appear and the seaside becomes a valuable viewpoint place.
\end{abstract}

Keywords: scenery structure, viewpoint, target of view, landform, land use, landscape キーワード : 風景構造, 視点場, 視対象, 地形, 土地利用, 景観

\section{1.はじめに}

21 世紀に入り, 成熟型の都市づくりへの転換が求められてき ている現在, 都市はより一層生活の場としての性格を強め, 地域 の自然や歴史的な環境に適合した各都市固有の風景を保全・創出 していくことが重要になってきている。このような時代背景の中 で, 景観法が平成 16 年 6 月に公布され, 景観計画の策定, 景観 計画区域や景観地区等の指定による良好な景観の形成を推進する ことが国政レベルでも位置づけられた。この中で，景観地区にお いては, 建物の形状やデザインに関する計画, 地区指定等を住民 からあ提案できるようになったことに見られるように, 住民参画 型の景観形成の推進が今後大いに期待されている。このような状 況の中で, 都市生活者が好ましいと評価する景観の特性を明らか にすることは, 今後の住民参画型の地域に根ざした景観形成を考 える上で，有意義であると考えられる。

都市景観に係わる既往研究をみると, 制度論, 手法論, 技術論 など多方面からアプローチされてきたといえる。このような既往 研究の中で, 鳴海ら ${ }^{1)}$ が都市の景観構造を名所図会から探り, 土 地自然に支配されていた近世の景観構造に立脚した景観計画の必 要性を述べていることや, 篠崎ら ${ }^{2)}$ は, 江戸名所図会に描かれて いる歳時記的要素から都市空間を捉えており, 各都市固有の景観 を形成する上で, 都市が立地する地形や歴史, 自然の移ろい性な どの重要性が指摘できる。また, 下村ら ${ }^{3)}$ は, 市民に好まれる風 景を構成する図と地の要素の関係や日变化や季節变化といった移 ろい性との関係を明らかにしている。その中で, 視点場の特性む 若干触れられているものの, 好まれる風景之地形分類や土地利用 分類との関係が明らかにされて抢らず，市域全体の風景構造を明 らかにするという課題も残されている。

そこで本研究では, 都市生活者の視点から評価される風景（大 阪市を対象にアンケート調査を通じて得た市民に好まれる景観調 查結果）を対象に，好まれる風景を捉えている視点場や視対象之 なる風景と，それらが分布する地形や土地利用との関係を探るこ
とによって, 都市の固有性に大きく影響すると考えられる風景構 造の解明を試みるとともに大都市大阪の今後の風景計画の方向性 を探ることを目的とした。

\section{2. 研究方法}

\section{（1）調查対象風景の抽出方法}

本研究では, 大阪市が指定景観形成物指定の基礎資料作成のた めに市民に対して実施した「わたしのまちの“打気に入りの景 観”」調査デー夕 (H.13.12〜H.14.2) と追加調查 $(H .15 .12 \sim H$. 16.2)）デー夕を用いた。本調査は“打気に入りの景観”を八ガ キ, FAX, Eメール，封筒にて募集したもので，各“打気に入 りの景観” の場所・名称, 魅力の中心とその選択理由について自 由記入方式で回答が求められている。な抢, このアンケート調査 は, 調査票のデザインから実施まで筆者の 1 人が市の景観委員会 の指定景観形成物指定部会の部会長として係わったものである。

調查対象風景は, 1 次調查の有効回答数 604 件に追加調査 294 件を合わせた 898 件・457 景の中から, 特定の個人しか利用でき ない視点場からの 4 景 (回答数が 4 件), 視点場もしくは視対象 を特定できない 21 景（46 件）をまず除いた。さらに，1つの景 に対して回答者が 1 人である 268 景（268 件）は偶発性や主観的 評価に偏る危険性が含まれることから除くこととした。その結果, 視点場之視対象が明確にわかり，かつ複数人が回答している 164 景（580 件）を抽出した。これらの好まれる風景の写真撮影は焦 点距離 $35 \mathrm{~mm}$ のカメラレンズを用いて平成 15 年 9 月〜 11 月に実施 したものに加え, 同様の方法で平成 16 年 8 月に実施した。撮影 時の視点場は, 自由記入方式での回答内容から特定し, 撮影対象 （視対象）は“魅力の中心”に記載されている景観の選択理由を あとに特定した。例えば，“㧍気に入りの景観”の名称が「御堂 筋沿道」, 場所が「大江橋から見た御堂筋の銀杏並木」, 魅力の中 心が「日本生命ビル＆並木」という自由記入方式の回答から, 視 点場は「大江橋南詰めの御堂筋東側の歩道上」, 視対象は「日本

\footnotetext{
*大阪府立大学大学院農学生命科学研究科
} 
生命ビルを含めた御堂筋のイチョウ並木」として特定した。なお， 高層建築物等の視点場の中で, 屋上や階数の記述のないむのにつ いては, 選択理由が「高層階からの眺望」と記述されていること から一般の人々が入ることのできる高層階のフロアーとした。ま た，城では天守閣，観覧車では最高到達点とした。

アンケート調査における被験者の属性は，性別では男性 537 件, 女性 358 件, 不明 3 件であり, 年齢では 10 歳代が 119 件, 20 歳 代が 95 件, 30 歳代が 199 件, 40 歳代が 114 件, 50 歳代が 116 件，,60 歳代以上が 201 件，不明 54 件であった。

\section{（2）好まれる風景構造の解析方法}

まず，好まれる風景は，好まれる風景を撮影した視点場の特性 と視対象である風景型の特性の 2 視点から

捉えるあのとした。

視点場の特性は，その位置を大きくオー プンスペース（以下 OS と表記），乗り物， 建築物，道路，橋に 5 分類し，さらに，そ の場の特性に応じて表 -1 の縦軸に示すよ うに 18 分類として捉えた。

風景型は, 表- 2 に示す 19 分類として 捉えた。まず，視対象之視点場との位置関 係から，視対象が視点場を内部に取り込ん だ景を環境型，視対象が視点場を含まず外 部から眺めている景を眺望型，視対象が視 点場を内部に取り込んだものから外部から 眺めている景までを含んだものを眺望十環 境型, 視対象が単一要素の景を単一型の大 きく 4 つに分類した。次いで，視対象を構 成する要素の特性に応じて，単一型は，巨 樹型之城や石碑などの歴史資源型，ビル型， およびそれら以外の人工物型に分類した。 環境型は, 面的な広がりのある樹林型, 線 的な並木型，水面型，社寺型，低層の住宅 を中心とする家並み型，商業・業務系の中 高層のビル群型に分類した。眺望型は，樹 林型，水面型に加え，遠景の山並み型，面 的に広がる市街地型, 山並みと市街地両方 を含む山並み十市街地型に分類した。環境 十眺望型は，水面型，ビル群型，樹林型十 ビル群型に分類して捉えた。

次いで，風景構造の解析は，164 景の撮 影位置をGIS（地理情報システム）を用い て地形分類図之土地利用分類図の上に布置 し, 5 大分類， 18 小分類から捉えた視点 場之 4 大分類，19 小分類から捉えた風景 型の出現数书よび分布特性から，市民が好 ましいと捉えた大阪市域全体の風景構造を 探った。

な抢，地形分類は，大阪府発行（1/100， 000，1976 年）の土地分類図を用い，埋立 地，自然堤防 - 砂洲，三角州性低地，扇状 地州低地, 段丘（中・低地）の 5 分類に, 河川・水路を加えて 6 分類で捉えた。また, 土地利用特性については大阪市発行（1／2 $5,000,2004$ 年）の用途地域図を用いて, 工業系地域, 商業系地域, 住宅系地域に 3 区分して捉えた。

3. 結果および考察
図一 1 は地形分類図上に好まれる風景の視点場を布置したもの を示し，図ー 2 は土地利用類型図上に同じく視点場を布置したも のを示している。また, 表 -1 と表一 2 は視点場抢よび風景型と 土地利用類型別の地形分類との関係を示している。

\section{（1）視点場の分布特性}

表 -1 より，まず視点場の分類ごとの出現数をみると，全 164 景中, OS が 60 景之最も多く全体の 4 割弱を占め，次いで，道 路が 38 景, 橋が 32 景と多くなっている。最も出現数の多かった OS を見ると公園が 25 景と多く，公園が好まれる風景を捉える 貴重な視点場となっていることが分かる。また，川辺 16 景と橋 32 景を合計すると河川・水路上あるいは沿川が視点場となって

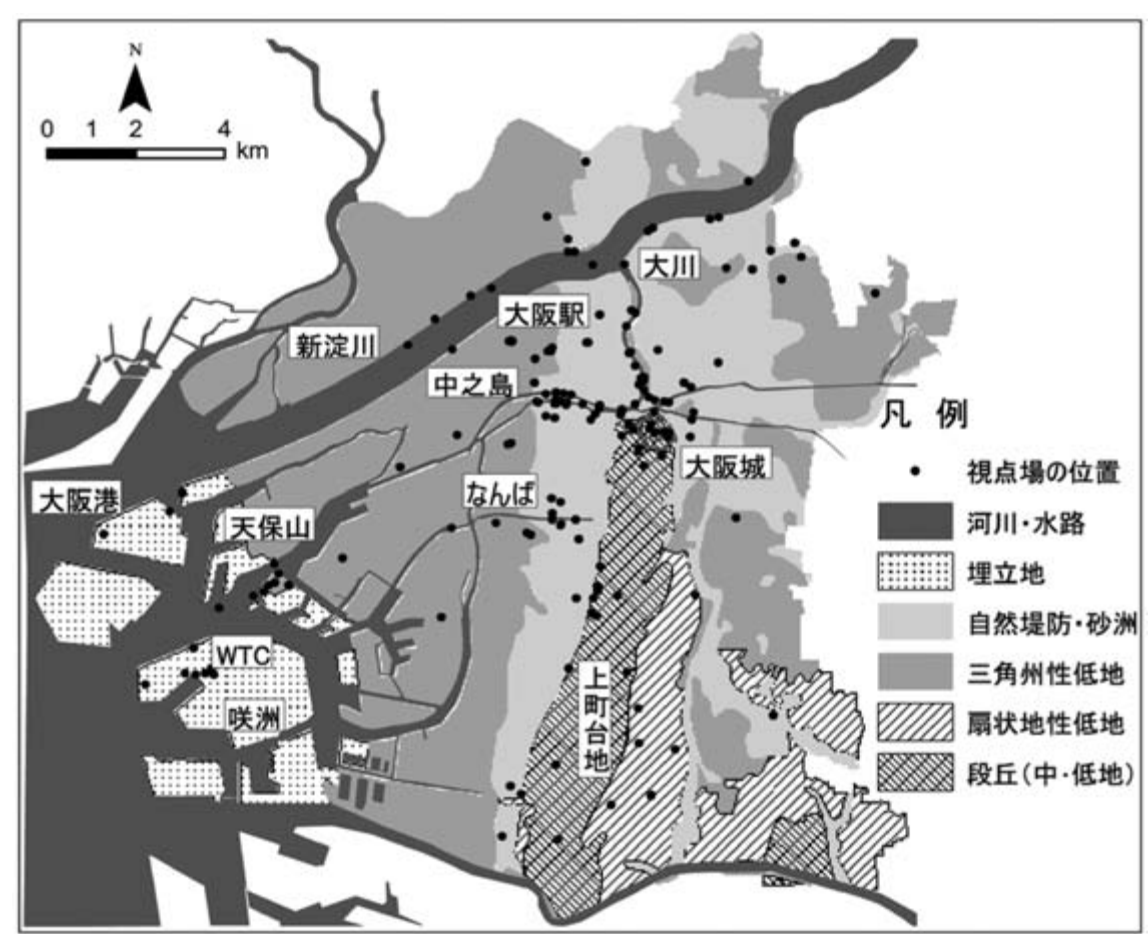

図－1 好まれる風景の視点場分布状況（地形分類）

表 -1 視点場と土地利用累型別の地形分類との関係

\begin{tabular}{|c|c|c|c|c|c|c|c|c|c|c|c|c|c|c|c|c|c|c|}
\hline \multirow[b]{2}{*}{ 視点場 } & \multicolumn{5}{|c|}{ 工歯系地域 } & \multicolumn{6}{|c|}{ 商童系地域 } & \multicolumn{6}{|c|}{ 住居系地域 } & \multirow[b]{2}{*}{ 絡尌 } \\
\hline & $\begin{array}{c}\text { 河川 } \\
\cdot \\
\text { 水路 }\end{array}$ & \begin{tabular}{|l} 
埋 \\
立 \\
地
\end{tabular} & $\begin{array}{l}\text { 自然 } \\
\text { 堤防. } \\
\text { 砂洲 }\end{array}$ & $\begin{array}{l}\text { 三角 } \\
\text { 州性 } \\
\text { 低地 }\end{array}$ & $\begin{array}{l}\text { 小 } \\
\text { 倽 } \\
\end{array}$ & $\begin{array}{l}\text { 河川 } \\
\text { 水路 }\end{array}$ & \begin{tabular}{|l} 
自然 \\
堤防. \\
砂洲
\end{tabular} & \begin{tabular}{|l} 
三角 \\
州性 \\
低地
\end{tabular} & $\begin{array}{l}\text { 艍状 } \\
\text { 地性 } \\
\text { 低地 }\end{array}$ & $\begin{array}{l}\text { 段丘 } \\
\text { (中. } \\
\text { 低地) }\end{array}$ & $\begin{array}{l}\text { 小 } \\
\text { 跍 }\end{array}$ & $\begin{array}{c}\text { 河川 } \\
\cdot \\
\text { 水路 }\end{array}$ & $\begin{array}{l}\text { 自然 } \\
\text { 堤防. } \\
\text { 砂洲 } \\
\end{array}$ & $\begin{array}{l}\text { 三角 } \\
\text { 絒性 } \\
\text { 低地 }\end{array}$ & \begin{tabular}{|l} 
局状 \\
地性 \\
低地
\end{tabular} & $\begin{array}{l}\text { 段丘 } \\
\text { (中. } \\
\text { 低地) }\end{array}$ & $\begin{array}{l}\text { 小 } \\
\text { 各 } \\
\end{array}$ & \\
\hline 海辺 & - & 5 & 2 & - & 7 & - & - & - & - & - & - & \begin{tabular}{|l|}
- \\
\end{tabular} & - & - & - & - & - & 7 \\
\hline 川辺 & - & 1 & 1 & - & 2 & - & 5 & - & $=$ & - & 5 & - & 4 & 5 & - & - & 9 & 16 \\
\hline 公園 & - & - & - & - & - & - & 3 & 3 & 1 & 1 & 8 & - & 2 & 2 & 4 & 9 & 17 & 25 \\
\hline 庭園 & $=$ & - & 1 & 1 & 2 & - & - & - & $=$ & - & - & - & 1 & - & - & 1 & 2 & 4 \\
\hline 広場 & $=$ & $=$ & - & - & - & $=$ & 1 & $=$ & $=$ & $=$ & 1 & - & $=$ & - & - & 1 & 1 & $?$ \\
\hline 社寺 & $=$ & $=$ & - & $=$ & - & $=$ & - & - & $=$ & - & - & $=$ & 1 & - & 1 & 4 & 6 & \\
\hline 小嘼 & $=$ & 6 & 4 & 1 & 11 & $=$ & 9 & 3 & 1 & 1 & 14 & $=$ & 8 & 7 & 5 & 15 & 35 & 60 \\
\hline 乘電重 & - & - & 1 & - & 1 & 2 & 3 & 3 & - & - & 8 & - & 1 & 2 & - & - & 3 & 12 \\
\hline り自動重 & 1 & - & - & - & 1 & - & 1 & 1 & $=$ & - & 2 & E- & $=$ & - & 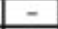 & - & - & 3 \\
\hline 物客船 & 3 & - & - & - & 3 & - & - & - & - & - & - & 1 & - & - & - & - & 1 & 4 \\
\hline 小話 & 4 & - & 1 & - & 5 & 2 & 4 & 4 & - & - & 10 & 1 & 1 & 2 & - & - & 4 & 19 \\
\hline 品高層 & - & 3 & - & 3 & 6 & - & - & 2 & $=$ & 1 & \begin{tabular}{|l|}
3 \\
\end{tabular} & - & $=$ & - & - & - & - & 9 \\
\hline 管低層 & - & 1 & 1 & - & 2 & - & $=$ & 1 & - & - & 1 & E- & - & - & $=$ & - & - & 3 \\
\hline 物城 & $=$ & - & - & - & - & - & - & 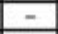 & $=$ & $=$ & - & $=$ & $=$ & $=$ & $=$ & 2 & 2 & 2 \\
\hline 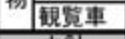 & $=$ & - & $=$ & - & $=$ & 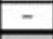 & $=$ & 1 & - & - & 1 & - & $=$ & - & $=$ & $=$ & $=$ & 1 \\
\hline 小䂥 & $=$ & 4 & 1 & 3 & 8 & - & $=$ & 4 & - & 1 & 5 & - & $=$ & $=$ & $=$ & 2 & 2 & 15 \\
\hline 広幅員 & - & 1 & - & - & 1 & - & 7 & 2 & - & 2 & 11 & - & - & - & - & - & - & 12 \\
\hline 道中幅員 & - & - & - & - & - & - & 6 & 1 & - & 2 & 9 & - & - & - & - & 1 & 1 & 10 \\
\hline 路路地 & - & - & - & - & - & - & 2 & - & - & - & 2 & - & 2 & 3 & - & 4 & 9 & 11 \\
\hline 离店街 & - & - & - & - & - & - & 3 & - & 1 & - & 4 & - & 1 & - & - & - & 1 & 5 \\
\hline 小䚺 & $=$ & 1 & - & $=$ & 1 & - & 18 & 3 & 1 & 4 & 26 & $=$ & 3 & 3 & $=$ & 5 & 11 & 38 \\
\hline 稢撟 & 4 & - & 1 & - & 5 & 17 & 1 & 1 & - & - & 19 & 5 & 1 & 2 & $=$ & - & 8 & 32 \\
\hline 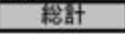 & 8 & 11 & 7 & 4 & 30 & 19 & 32 & 15 & 2 & 6 & 74 & 6 & 13 & 14 & 5 & 22 & 60 & 164 \\
\hline
\end{tabular}


いるものが 48 景となり, 河川・水路が貴重な視点場となってい ることが明らかとなり，大阪市の特徴を表していると考えられる。

土地利用類型別の全体傾向をみると, 全 164 景中, 商業系地域 が 74 景と 5 割弱を占めており, 次いで, 住宅系地域が 60 景と多 く, 工業系地域が 30 景と少ない状況にある。大阪市の中心部に 位置する商業系地域は, 面積割合が少ないものの好まれる風景が 半数近くこの地域から捉えられており, 都市活動の集積が影響し ているあのと考えられる。また, 市域の東部や南部に主に分布す る住宅系地域に 60 景も出現している点は, 今後の風景計画を考 える上で有効に働くあのと考えられる。

次いで, 視点場の分布特性を土地利用類 型をべースに地形分類別に捉える。

商業系地域は，その大部分が上町台地の 西側に広がる自然堤防・砂洲から三角州性 低地の一部にかけて立地している。この商 業系地域では, 自然堤防・砂洲を視点場と した風景が 32 景と突出して多く, 同じく 上町台地の西側に位置する大川・道頓堀川 という河川・水路が 19 景と多くなってい る。突出して視点場が集中している自然堤 防・砂洲のエリアは, 船場地区と呼ばれ近 世からの都心部に当たる。ここでは, 高層 高密化していることから, 一定以上の幅員 を持つ線上の空き空間である道路が貴重な 視点場を提供していることが分かる。また， 河川・水路上の橋もこのエリアに集中して おり, 水面が貴重な引き空間となって好ま れる風景が捉えられているあのと考えられ る。

住居系地域は, 上町台地を構成する段丘 （中・低地）や市の東部に位置する三角州 性低地, 上町台地西部に広がる自然堤防・ 砂洲に多く立地している。この内, 視点場 は, 段丘（中・低地）が 22 景之顕著に多 く, 市東部の三角州性低地之上町台地西側 の自然堤防・砂洲がそれぞれ 14 景, 13 景 と多い。突出して多く視点場が集中してい る段丘（中・低地）のエリアでは, OS が 15 景之最も多く, 中でも公園が 9 景と多 くなっているが，その大部分は段丘上に位 置する大阪城公園である。また，段丘の東 斜面に分布する社寺む 4 景とやや多くなっ ている。また, 道路が 5 景とやや多く, そ の大部分が路地である。一方, 三角州性低 地では, OS が 7 景と多く, これらは川辺 ( 5 景) と公園 (2 景) に集中しているが, これは大川（旧淀川）との合流地点付近で ある。

工業系地域においては, 埋立地を視点場 とした風景が 11 景と最も多く, 河川・水 路が 8 景, 自然堤防・砂洲が 7 景とやや多 くなって抢り, 市東部内陸部の工業系地域 では視点場がほとんど無いことを示してい る。視点場の集中する埋立地では海辺とそ こに立地する超高層建築物が貴重な視点場 を提供していることが分かる。また，客船 が 3 景あり，海上からの眺望も好まれてい ることが分かる。

\section{（2）風景型の分布特性}

表一 2 より, まず風景型ごとの出現数をみると, 全 164 景中, 環境型が 64 景, 眺望型が 61 景とこれらの風景型がほぼ同程度に 多く, 単一型が 31 景之続いている。一方, 眺望+環境型は 8 景 と非常に少なくなっている。環境型ではビル群型, 樹林型, 並木 型, 水面型が 13〜15 景とほぼ同程度に出現し, 大都市にもかか わらずビル群型が少ないのが意外である。一方, 眺望型では市街 地型が 27 景と突出して多く, 次いで，水面型が 22 景と続いてお り, 大都市としての特徵と水都としての特徵を表していると考え られる。また, 眺望十環境型が非常に少ないことや単一型が多い

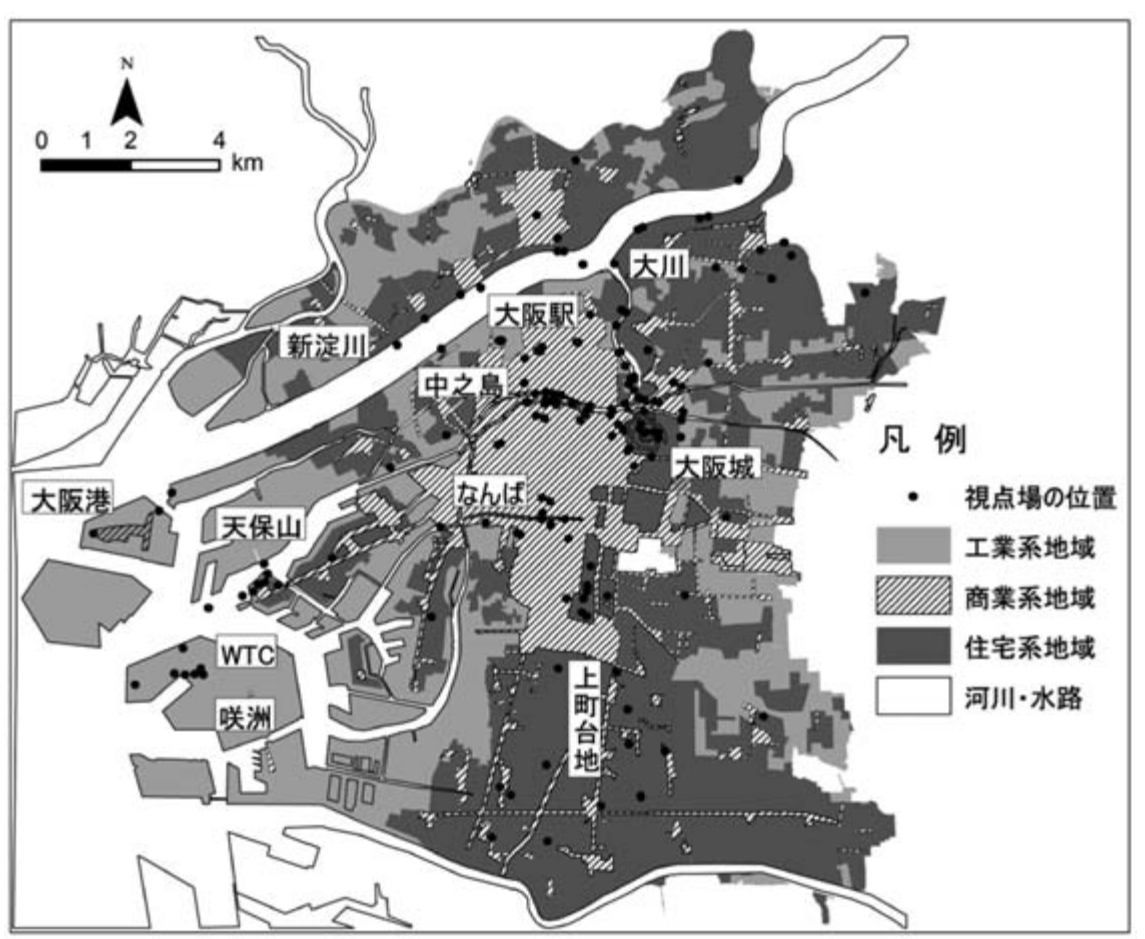

図－２好まれる風景の視点場分布状況（土地利用類型）

表 -2 風景型亡土地利用累型別の地形分類との関係

\begin{tabular}{|c|c|c|c|c|c|c|c|c|c|c|c|c|c|c|c|c|c|c|}
\hline \multirow[b]{2}{*}{ 風景型 } & \multicolumn{5}{|c|}{ 工童系地域 } & \multicolumn{6}{|c|}{ 商菜系地域 } & \multicolumn{6}{|c|}{ 住居系地域 } & \multirow[b]{2}{*}{ 稆計 } \\
\hline & $\begin{array}{l}\text { 河川 } \\
\text { 水路 }\end{array}$ & \begin{tabular}{|l|} 
埋 \\
咅 \\
地
\end{tabular} & 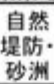 & 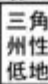 & $\begin{array}{l}\text { 小 } \\
\text { st }\end{array}$ & $\begin{array}{l}\text { 河川 } \\
\text { 水路 }\end{array}$ & 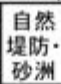 & 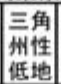 & \begin{tabular}{|l} 
屋状 \\
地惟 \\
低地
\end{tabular} & $\begin{array}{l}\text { 段乒 } \\
\text { (中) } \\
\text { 低地 }\end{array}$ & $\begin{array}{l}\text { 小 } \\
\text { 竍 }\end{array}$ & $\begin{array}{l}\text { 河川 } \\
\text { 水路 }\end{array}$ & \begin{tabular}{|l} 
自然 \\
塂防. \\
现济
\end{tabular} & 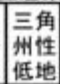 & $\begin{array}{l}\text { 局状 } \\
\text { 地性 }\end{array}$ & $\begin{array}{l}\text { 段乒 } \\
\text { (中. } \\
\text { 坻地) }\end{array}$ & 小 & \\
\hline 医唄型 & - & - & - & - & - & - & - & - & - & - & - & - & 2 & - & - & - & 2 & 2 \\
\hline 虚史㣀産型 & - & - & - & - & - & - & 5 & 1 & - & 1 & 7 & - & 1 & - & - & 1 & 2 & 9 \\
\hline 单度型 & - & - & 2 & - & 2 & 1 & 2 & - & - & - & 3 & - & - & 2 & - & - & 2 & 7 \\
\hline ビル型 & - & - & - & 1 & 1 & 3 & 2 & - & - & 1 & 6 & - & 1 & 1 & $\overline{-}$ & 2 & 4 & 11 \\
\hline 人工物型 & - & - & - & - & - & 1 & - & - & - & - & $\begin{array}{ll}1 \\
\end{array}$ & - & - & 1 & - & - & 1 & 2 \\
\hline 小矿 & - & - & 2 & 1 & 3 & 5 & 9 & $\frac{1}{1}$ & - & 2 & 17 & $\overline{-}$ & $\frac{4}{4}$ & 4 & - & $\overline{3}$ & 11 & 31 \\
\hline 䐪林型 & $\overline{-}$ & - & $T$ & - & \begin{tabular}{|l|l|l}
1 & \\
\end{tabular} & 1 & $T$ & 2 & - & - & 4 & - & 2 & $\frac{1}{1}$ & 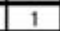 & 5 & 9 & 14 \\
\hline 亚木㤠 & - & - & - & - & - & - & 7 & 2 & - & 2 & 11 & - & - & 1 & - & 1 & 2 & 13 \\
\hline 现 永面型 & - & 3 & 2 & - & 5 & - & 2 & 1 & - & - & 3 & - & 1 & - & 1 & 3 & \begin{tabular}{|l|l}
5 \\
\end{tabular} & 13 \\
\hline 境社寺㤠 & - & - & - & - & - & - & - & - & - & - & - & - & 2 & - & 1 & - & 3 & 3 \\
\hline 家並み型 & - & - & - & - & - & - & - & 1 & - & - & 1 & - & - & 2 & - & 3 & 5 & 6 \\
\hline ビル群型 & - & - & - & - & - & 2 & 8 & - & 1 & 1 & 12 & 1 & - & 1 & $\begin{array}{l}- \\
-\end{array}$ & 1 & 3 & 15 \\
\hline 小却 & - & 3 & 3 & - & 6 & 3 & 18 & $\overline{6}$ & 1 & 3 & 31 & 1 & 5 & 5 & 3 & 13 & 27 & 64 \\
\hline 胿林型 & - & 1 & - & - & 1 & - & - & 1 & $\frac{1}{1}$ & - & 2 & - & - & 1 & 2 & - & 3 & 6 \\
\hline 水面型 & 3 & 4 & 1 & - & 8 & 6 & 2 & - & - & - & 8 & 3 & 2 & 1 & - & - & 6 & 22 \\
\hline 眺山並み型 & - & - & - & - & - & - & - & - & - & - & - & - & - & 1 & - & - & 1 & 1 \\
\hline 望 山亚み+ & 1 & 2 & - & - & 3 & - & - & - & - & - & - & 1 & - & - & - & 1 & 2 & 5 \\
\hline 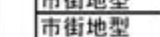 & 4 & 1 & 1 & 3 & 9 & 2 & 2 & 7 & - & 1 & 12 & 1 & - & 2 & - & 3 & (6 & 27 \\
\hline 小部 & 8 & 8 & $\frac{1}{2}$ & $\frac{5}{3}$ & 21 & 8 & $\frac{5}{4}$ & 8 & $\frac{T}{1}$ & 1 & 22 & 5 & 2 & 5 & 2 & $\frac{5}{4}$ & 18 & 61 \\
\hline 现水面型 & - & - & - & - & - & 3 & - & - & - & - & 3 & - & 2 & - & - & - & 2 & 5 \\
\hline 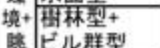 & - & - & - & - & - & - & 1 & - & - & - & 1 & - & - & - & - & 1 & 1 & 2 \\
\hline 望 ビル群型 & - & - & - & - & $=$ & - & - & - & - & - & - & - & - & - & - & 1 & 1 & 1 \\
\hline 小碚 & $=$ & $=$ & $\overline{-}$ & - & - & 3 & 1 & - & $\overline{-}$ & $\overline{-}$ & \begin{tabular}{|l|l}
4 \\
\end{tabular} & - & 2 & $\overline{-}$ & - & 2 & \begin{tabular}{|l|}
4 \\
\end{tabular} & 8 \\
\hline 榣䃌 & 8 & & & & & & $\overline{32}$ & & & & & & 13 & & & & & 164 \\
\hline
\end{tabular}


ことは，風景の多様性を喪失していることを伺わせる。

次いで, 風景型の特性を土地利用類型をべースに地形分類別に 捉える。

商業系地域においては，上町台地の西側に広がる自然堤防・砂 洲上のエリアの全 32 景中, 環境型が 18 景と最も多く, その内訳 はビル群型が 8 景, 並木型が 7 景とこれら両風景型に集中してい る。次いで, 単一型が 9 景と多く, その内訳をみると, 歴史資産 型が 5 景と多いことが特徽的である。河川・水路上の全 19 景中 では, 眺望型が 8 景と最む多く, その内訳を見ると水面型の 6 景 に集中していることや単一型の 5 景ではビル型が 3 景と多いこと が分かる。これらのエリアは船場地区と呼ばれ現在では高層高密 化した市街地であるが，水面型の風景や並木型の風景が多いこと や歴史資産型が含まれることから水都としての面影を残している ことや並木を伴った幅員の広い道路という都市の基盤施設がある 程度整っていることを伺わせている。

住居系地域においては, 段丘（中・低地）上エリアの全 22 景 中, 環境型が 13 景と最も多く, 社寺型を除いて多様な風景型が 出現していることが特徽的である。一方, このエリアは平坦地形 の中にある唯一の微高地であり, 社寺が多く立地しているにもか かわらず眺望型の風景や社寺型の風景がほとんど捉えられておら ず, 既に台地としての特性や歴史的エリアとしての特性が喪失さ れていることを伺わせている。

工業系地域においては, 埋立地上の全 11 景之河川・水路上の 全 8 景中, 眺望型がいずれも 8 景と突出して多く, その約半数を 水面型が占めることは, このエリアが河口部や海上に立地すると いう特徴を反映している。また, 山並み+市街地型が計 3 景出現 し, 内陸部での商業系地域では見えなくなった大阪平野を囲む周 辺の山系が眺望されていることが特徵的である。

\section{4.まとめ}

これまで明らかにした地形や土地利用との関係で捉えた視点場 の分布特性や風景型の分布特性を踏まえ, 大阪市域という都市全 体の風景構造を探った結果, 今後の大都市大阪の景観計画に向け た方向性として, 以下の 4 点が考察される。

(1)市域全域に扔ける風景構造

・各種の OS や河川・水路上に架かる橋梁が貴重な視点場となっ ている。

・風景型の多くを占める環境型や眺望型の中では樹林型や並木型, 水面型が多くを占め, 特に, 河川・水路上に架かる橋梁やそこを 渡る車空は，市民が好む風景を捉える貴重な視点場となっている。 ・河川・水路の水面は視対象としても貴重である。

- 近代以降営々之造営されてきた公園む河川・水路に次いで貴重 な視点場となるとともに, 風景型の中の樹林型に見られるように 貴重な視対象ともなっている。

従って, 近代以降の都市集積が著しい大阪市域にあって河川・ 水路は近世に「水の都」之謳われた大阪の個性を継承する風景構 造の基盤ともなっている。また, 公園も河川・水路同様に風景構 造の基盤を担っていると考えられる。

(2)商業系地域における風景構造

・主に上町台地の西側に広がる自然堤防・砂洲上のエリアは, 船 場地区と呼ばれ近世から続く都心部に当たり, 現在も高層高密化 した商業系地域となっており, 都市活動の集積によって市民に好 まれる風景を捉える視点場が集積している。

・当エリアでは, 一定以上の幅員を持つ線上の空き空間である道 路と近世に造営された堀川が貴重な視点場を提供しているととも に, 視点場を内包した環境型の水面型風景や並木型風景として好 まれている。
従って, 商業系地域では, 水都大阪の個性を残す堀川とともに 並木を伴った広幅員の道路が当エリアの風景構造を形成している あのと考えられる。

(3)住居系地域における風景構造

-上町台地南部の段丘（中・低地）や扇状地性低地，東部に広が る自然堤防・砂洲にも，市民に好まれる風景を捉える視点場が多 く出現するとともに，多様な風景型が分布する。

・住居系地域では, 共通して公園や路地が格好の視点場を提供し ており，ヒューマンスケールの身近な緑や古くからの路地がこの エリアの風景構造の基盤となっている。特に, 上町台地上に広が るエリアでは, 多様な風景型が捉えられている。

・しかし, 当エリアで捉えられている風景型は, 眺望型ではなく 環境型が大部分を占めている点や社寺型が少なくなっている。

・そのような中で, 上町台地の北端に位置する大阪城を含む大阪 城公園には多くの視点場が集積し，台地の北部に広がる三角州低 地では大川（旧淀川）の合流地点に視点場がやや集中している。

従って, 住居系地域では, 中遠景を捉える眺望型に適した段丘 （中・低地）上の台地の特性や社寺型といった歴史の特性が喪失 されてしまっていることが伺え，大阪の都市風景の固有性を発揮 する上では大きな損失といえる。しかし，大坂城周辺エリアは， 平坦地が大部分を占める大阪に扔いて風景構造を特徽づける上町 台地を象徵し, 風景構造上の貴重なエリアといえる。また, 台地 北部の三角州低地に打ける視点場の多さは, 上町台地との境界部 にあって, 地形の変局点の重要性を伺わせている。

(4)工業系地域に打ける景観構造

・工業系地域の中の河口部之海上に広がる埋立地のエリアでは, まだまだ好まれる風景が少ないものの超高層建築物や船上といっ た新たな視点場が出現している。

・また，大阪平野を取り囲む周辺山系を視対象とした眺望型の風 景が捉えられている。

従って, 工業地系地域の中でも特に埋立地では, 超高層建築物 や船上といった新たな視点場の出現と周辺山系を望む眺望型の風 景が，大阪の風景構造を特徵付けるものといえる。

以上の上うに, 上町台地の特性や歴史の特性が一部失われてい るものの, 現在の都市生活者からの目を通じても, 近世の水都大 阪を支えた堀川や大川（旧淀川）の合流点之その南側に広がる大 阪城公園に代表される段丘（中・低地）で形成された上町台地が 今なお大都市大阪の風景構造の基盤をなしているといえ, これら を基調として都市全体の風景の再統合化や文脈の回復を図ること によって, 失われつつある都市の個性が再生できるものと考えら れる。一方, 近代以降営々と造営してきた並木を伴った広幅員の 道路や公園, 海辺や河口部に展開する埋立地での超高層建築は, 風景構造の新たな基盤をなしているものであり，これらを基調と して都市全体の風景の統合化を図ることによって，混乱した都市 の風景に一定の秩序を与えることができるものと考えられる。

\section{引用・参考文献}

1）鳴海邦碩・久隆浩・橋爪紳也・大西二州（1988）:『浪花百景』 に描かれた近世大阪の都市景観構造に関する考察：日本都市 計画学会学術研究論文集 23, 223-228

2 ) 篠崎伸・志摩邦雄・小柳武和（1998）：歳時記的要素に配慮 した都市の空間構成に関する研究一「ひたち都市環境写真コ ンテスト」応募作品と「江戸名所図会」の分析ー：日本都市 計画学会学術研究論文集 33, 727-732

3 ）下村泰彦・有本幸代・王荵・増田昇（2004）：大阪市におけ る市民に好まれる風景の空間構成抢よび移ろい性に関する研 究：日本造園学会ランドスケープ研究 67(5), 619-622 